\title{
PREVALENCE OF VIRULENCE GENES OF SOME FOODBORNE BACTERIA IN CHICKEN MEAT PRODUCTS
}

\author{
NASHWA, M. ZAKI ${ }^{1}$; EL-DOSOKY. H.F.A ${ }^{1}$; and WAFAA, M. GAD ${ }^{2}$ \\ ${ }^{1}$ Food Hygiene Dept. Mansoura Provential Lab, Animal Health Research Institute, Egypt \\ ${ }^{2}$ Microbiololgy Dept. Mansoura Provential Lab, Animal Health Research Institute, Egypt
}

Received: 23 March 2017; Accepted: 13 April 2017

\begin{abstract}
This Study was carried out on 200 random samples of chicken meat products represented by chicken luncheon, chicken burger, chicken sausage and chicken shawerma (50 of each). Samples were randomly collected from different supermarkets and retailers of different sanitation levels at Mansoura city, El Dakahlia Province, Egypt and bacteriologically analyzed to assess the prevalence of Staph. aureus, E. coli and S. spp. and their enterotoxigenic virulence genes using PCR in some chicken meat products intended for direct consumption. The obtained results revealed that the prevalence of Staph. aureus in examined chicken luncheon, chicken burger, chicken sausage and chicken shawerma were $6 \%, 2 \%, 2 \%$ and $2 \%$., respectively. While E. coli were $2 \%$, $4 \%$, $0 \%$ and $2 \%$ in examined samples respectively and $S$. spp. was isolated by $2 \%$ from shawerma only. The isolated $S$. typhimurium harbor invA and stn genes. The isolated E. coli showed presence of shiga toxin genes (stx 1 and stx2). The examined coagulase positive Staph. aureus showed the presence of different enterotoxin genes sea, $s e b, s e c$, sed and see. Thus it is necessary to adopt a regime of good, safe and healthy production of such chicken meat products with cleaning and disinfection and hygienic packaging in order to ensure safe products for consumers.
\end{abstract}

Key words: Prevalence, Virulent Genes, Foodborne Bacteria, Chicken, Meat Products.

\section{INTRODUCTION}

Poultry meat and its products are very popular food throughout the world, it considered as cheap, good delicious and nutritious, source of protein with good flavour and easily digestion. Ready to eat food can be described as the status of food being ready for immediate consumption at the point of sale, it may be raw or cooked, and can be consumed without further treatment Tsang (2002). The importance of food as a vehicle for transmission of several diseases has been documented, especially in developing countries where the hygienic standards are not strictly followed or enforced Harakeh et al. (2005). Staph. aureus produces a wide variety of toxins including staphylococcal enterotoxins (SEs; SEA to SEE, SEG to SEI, SER to SET) with demonstrated emetic activity, SEs are a major cause of food poisoning, which typically occurs after ingestion of different foods, particularly chicken meat products, contaminated with Staph. aureus by improper handling and subsequent storage at elevated temperatures

Corresponding author: Dr. NASHWA, M. ZAKI

E-mail address: nashwazaki80@gmail.com

Present address: Food Hygiene Dept. Mansoura Provential Lab, Animal Health Research Institute, Egypt
Tharwat and Elabbasy (2014). Salmonellosis was one of the most commonly zoonotic disease accounting for 133,258 confirmed humancases Osek and Wieczorek (2010). Salmonella often present in fresh tissues due to defects during slaughtering process of poultry and carcass manipulation Lee et al. (1998) as well as Cebedo et al. (2008) concluded that S. spp. are pathogenic bacteria that can contaminate food products during or after processing. Hamilton et al. (2009) mentioned that E.coli was isolated from $60 \%$ of examined poultry from butcher shops with mean counts of $0.70 \log _{10} \mathrm{cfu} / \mathrm{g}$. and $16 \%$ from poultry sold in supermarket samples with mean counts of 0.51 $\log _{10}$ cfu/g. Matossian and Kingcott (1979) detected food poisoning outbreak from donar kebab (a product similar to shawerma). Staphylococcus spp., E.coli and $S$. spp. were isolated from raw chicken products and chicken shawerma Kaneko et al. (1999) and Pelczar et al., 2006). Shiga toxin (Stx)-producing E. coli (STX-EC), also known as Verotoxin-producing $E$. coli which associated with infantile diarrhea, haemorrhagic colitis, thrombocyticpurpura, and hemolytic uremic syndrome in humans Griffin and Tauxe (1991). The aim of this study was to assess the presence of these bacteria in some chicken meat products and the risk of contamination on the consumer. 


\section{MATERIALS AND METHODS}

\section{1- Collection of samples:}

Two hundred samples of chilled chicken meat products (50 samples each of chicken luncheon, chicken burger, chicken sausage and chicken shawerma) at $\pm 4^{\circ} \mathrm{C}$ were collected aseptically from different shops (small grocery and large supermarkets) from Mansoura city, Dakahlia province and transferred to the laboratory in an insulated ice-box without delay.

\section{2- Bacteriological examination:}

2.1- Preparation of food homogenate: according to technique recommended by ISO, 6887-2, (2003) $25 \mathrm{~g}$. of each sample was removed by a sterile scissors and forceps and stomached using Seward stomacher 80 biomaster England with $225 \mathrm{ml}$ sterile buffered peptone water $(0.1 \%)$ to give a homogenate of $1 / 10$ dilution from which ten fold serial dilutions were prepared and subjected to the following bacteriological examination.

2.2- Total E.coli count: according to technique recommended by FDA (2002a).

2.3- Staphylococcus aureus count: FDA (2002b). using Baird-Parker agar plates, incubated at $35{ }^{\circ} \mathrm{C}$ for $48 \mathrm{hr}$. The suspected Staphaureus colonies were isolated, purified and confirmed by coagulase test and the total count was calculated.

2.4- Isolation of $\boldsymbol{E}$. coli according to technique recommended by ISO, 16649/2, (2001)

2.5- Isolation of Salmonellae ISO, 6579 (2002): by enrichment in peptone water at $\left(37{ }^{\circ} \mathrm{C}\right.$ for $\left.24 \mathrm{hr}\right)$ then selection enrichment in Tetrathionate $\left(37^{\circ} \mathrm{C}\right.$ for $\left.24 \mathrm{hr}\right)$ and rappaportvasiliades at $41.5{ }^{\circ} \mathrm{C}$ for $18 \mathrm{hr}$., platting on XLD, MaCconkey's and Hektoneentreic agar at $37^{\circ} \mathrm{C}$ for $24 \mathrm{hr}$. The presumptive colonies were confirmed biochemically and serologically.

3- Detection of virulence genes in Staphaureus, $\boldsymbol{E}$. coli and Salmonella using PCR:
Carried out in Reference Lab for Quality Control on Poultry Production, Animal Health Research Institute, Dokki-Egypt.

\section{1- DNA extraction:}

DNA extraction from positive samples were(6 Staph. aureus), (4E. coli) and (1 Salmonella) performed using the QIAamp DNA Mini kit (Qiagen, Germany, $\mathrm{GmbH}$ ) with modifications from the manufacturer's recommendations. Briefly, $200 \mu \mathrm{l}$ of the sample suspension was incubated with $10 \mu \mathrm{l}$ of proteinase $\mathrm{K}$ and $200 \mu \mathrm{l}$ of lysis buffer at $56^{\mathrm{O}} \mathrm{C}$ for $10 \mathrm{~min}$. After incubation, $200 \mu \mathrm{l}$ of $100 \%$ ethanol was added to the lysate. The samplewas then washed and centrifuged following the manufacturer's recommendations. Nucleic acid was eluted with $100 \mu$ l of elution buffer provided in the kit.

\section{2- Oligonucleotide Primers:}

The used Primers used were supplied from Metabion (Germany) are listed in Table (I) and Table (II).

\section{3- PCR amplification:}

For uniplex PCR, primers were utilized in a $25-\mu 1$ reaction containing $12.5 \mu \mathrm{l}$ of Emerald Amp Max PCR Master Mix (Takara, Japan), $1 \mu l$ of each primer of 20 pmol concentrations, $4.5 \mu$ l of water, and $6 \mu 1$ of DNA template. For stx1, stx2 duplex PCR, primers were utilized in a 50- $\mu 1$ reaction containing $25 \mu 1$ of Emerald Amp Max PCR Master Mix (Takara, Japan), $1 \mu \mathrm{l}$ of each primer of $20 \mathrm{pmol}$ concentration, $13 \mu \mathrm{l}$ of water, and $8 \mu \mathrm{l}$ of DNA template. The reaction was performed in an appliedbiosystem 2720.

\section{4- Analysis of the PCR Products:}

The products of PCR were separated by electrophoresis on $1.5 \%$ agarose gel (Applichem, Germany, GmbH) in $1 \mathrm{x}$ TBE buffer at room temperature using gradients of $5 \mathrm{~V} / \mathrm{cm}$. For gel analysis, $20 \mu \mathrm{l}$ of the uniplex PCR products and $30 \mu \mathrm{l}$ of the duplex PCR products were loaded in each gel slot. Generuler 100 bp ladder (Fermentas, Thermo Scientific, Germany) was used to determine the fragment sizes. The gel was photographed by a gel documentation system (Alpha Innotech, Biometra) and the data was analyzed through computer software. 
Table I: primer sequence for Staph. aureus enterotoxins genes used in multiplex PCR (Mehrotra et al., 2000).

\begin{tabular}{|c|c|c|}
\hline Primer pairs & Nucleotide sequence $\left(5^{\prime} \rightarrow 3^{\prime}\right)$ & Amplicon size (bp) \\
\hline $\begin{array}{l}\text { sea } \\
\text { Forward } \\
\text { Reverse }\end{array}$ & $\begin{array}{l}\text { 5 GGTTATCAATGTGCGGGTGG 3` } \\
5 \text { CGGCACTTTTTTCTCTTCGG 3` }\end{array}$ & 102 bp \\
\hline $\begin{array}{c}\text { seb } \\
\text { Forward } \\
\text { Reverse }\end{array}$ & 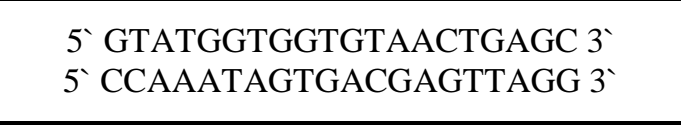 & $164 \mathrm{bp}$ \\
\hline $\begin{array}{l}\text { sec } \\
\text { Forward } \\
\text { Reverse }\end{array}$ & $\begin{array}{c}5 \text { 'AGATGAAGTAGTTGATGTGTATGG 3` } \\
\text { 5 CACACTTTTAGAATCAACCG 3` }\end{array}$ & $451 \mathrm{bp}$ \\
\hline $\begin{array}{c}\text { sed } \\
\text { Forward } \\
\text { Reverse } \\
\end{array}$ & $\begin{array}{c}5^{`} \text { CCAATAATAGGAGAAAATAAAAGG 3` } \\
5{ }^{`} \text { ATTGGTATTTTTTTTCGTTC } 3{ }^{`}\end{array}$ & 278 bp \\
\hline $\begin{array}{l}\text { see } \\
\text { Forward } \\
\text { Reverse }\end{array}$ & $\begin{array}{l}\text { 5`AGGTTTTTTCACAGGTCATCC 3` } \\
\text { 5 `TTTTTTTTCTTCGGTCAATC 3` }\end{array}$ & $209 b p$ \\
\hline
\end{tabular}

Table II: Primers sequences, target genes, amplicon sizes and cycling conditions.

\begin{tabular}{|c|c|c|c|c|c|c|c|c|}
\hline \multirow{2}{*}{$\begin{array}{l}\text { Target } \\
\text { gene }\end{array}$} & \multirow{2}{*}{ Primers sequences } & \multirow{2}{*}{$\begin{array}{l}\text { Amplified } \\
\text { segment } \\
\text { (bp) }\end{array}$} & \multirow{2}{*}{$\begin{array}{c}\text { Primary } \\
\text { denaturation }\end{array}$} & \multicolumn{3}{|c|}{ Amplification ( 35 cycles) } & \multirow{2}{*}{$\begin{array}{c}\text { Final } \\
\text { extension }\end{array}$} & \multirow{2}{*}{ Reference } \\
\hline & & & & $\begin{array}{l}\text { Secondary } \\
\text { denaturation }\end{array}$ & Annealing & Extension & & \\
\hline \multirow{3}{*}{ stn } & TTG TGT CGC TAT & \multirow{3}{*}{617} & \multirow{3}{*}{$\begin{array}{l}94^{\circ} \mathrm{C} \\
5 \mathrm{~min} .\end{array}$} & \multirow{3}{*}{$\begin{array}{l}94^{\circ} \mathrm{C} \\
30 \mathrm{sec} .\end{array}$} & \multirow{3}{*}{$\begin{array}{l}59^{\circ} \mathrm{C} \\
45 \mathrm{sec} .\end{array}$} & \multirow{3}{*}{$\begin{array}{l}72^{\circ} \mathrm{C} \\
45 \mathrm{sec} .\end{array}$} & \multirow{3}{*}{$\begin{array}{c}72^{\circ} \mathrm{C} \\
10 \mathrm{~min}\end{array}$} & \multirow{3}{*}{$\begin{array}{c}\text { Murugkar } \\
\text { et al., } 2003\end{array}$} \\
\hline & CAC TGG CAA CC & & & & & & & \\
\hline & $\begin{array}{l}\text { ATT CGT AAC CCG } \\
\text { CTC TCG TCC }\end{array}$ & & & & & & & \\
\hline \multirow{3}{*}{$\operatorname{inv} A$} & GTGAAATTATCGC & \multirow{3}{*}{284} & \multirow{3}{*}{$\begin{array}{l}94^{\circ} \mathrm{C} \\
5 \mathrm{~min} .\end{array}$} & \multirow{3}{*}{$\begin{array}{c}94^{\circ} \mathrm{C} \\
30 \mathrm{sec} .\end{array}$} & \multirow{3}{*}{$\begin{array}{c}55^{\circ} \mathrm{C} \\
30 \mathrm{sec} .\end{array}$} & \multirow{3}{*}{$\begin{array}{l}72^{\circ} \mathrm{C} \\
30 \mathrm{sec} .\end{array}$} & \multirow{3}{*}{$\begin{array}{l}72^{\circ} \mathrm{C} \\
7 \mathrm{~min}\end{array}$} & \multirow{3}{*}{$\begin{array}{l}\text { Oliveira } \\
\text { et al., } \\
2003\end{array}$} \\
\hline & CACGTTCGGGCAA & & & & & & & \\
\hline & $\begin{array}{l}\text { TCATCGCACCGTC } \\
\text { AAAGGAACC }\end{array}$ & & & & & & & \\
\hline \multirow{3}{*}{ Stxl } & $\begin{array}{l}\text { ACACTGGATGATC } \\
\text { TCAGTGG }\end{array}$ & \multirow{3}{*}{614} & \multirow{6}{*}{$\begin{array}{l}94^{\circ} \mathrm{C} \\
5 \mathrm{~min} .\end{array}$} & \multirow{6}{*}{$\begin{array}{l}94^{\circ} \mathrm{C} \\
30 \mathrm{sec} .\end{array}$} & \multirow{6}{*}{$\begin{array}{c}58^{\circ} \mathrm{C} \\
45 \mathrm{sec} .\end{array}$} & \multirow{6}{*}{$\begin{array}{l}72^{\circ} \mathrm{C} \\
45 \mathrm{sec} .\end{array}$} & \multirow{6}{*}{$\begin{array}{c}72^{\circ} \mathrm{C} \\
10 \mathrm{~min} .\end{array}$} & \multirow{6}{*}{$\begin{array}{c}\text { Dipineto } \\
\text { et al., } \\
2006\end{array}$} \\
\hline & CTGAATCCCCCTC & & & & & & & \\
\hline & CATTATG & & & & & & & \\
\hline \multirow{3}{*}{ Stx 2} & CCATGACAACGGA & \multirow{3}{*}{779} & & & & & & \\
\hline & CAGCAGTT & & & & & & & \\
\hline & $\begin{array}{c}\text { CCTGTCAACTGAG } \\
\text { CAGCACTTTG }\end{array}$ & & & & & & & \\
\hline
\end{tabular}

\section{Statistical analysis:}

The results are expressed as mean \pm standard Error (SE). Data were statistically analyzed using statistical analysis systems. (SAS version 9.1, SAS Institute, Inc., 2003).

\section{RESULTS}

The achieved results of Staph. aureus in Tables (1 \& 2) for Chicken luncheon, Chicken burger, Chicken sausage and Chicken shawerma were $3.2 \pm 1.6,3.5 \pm 1.5,3.6 \pm 1.4$ and $3.7 \pm 1.3 \log _{10} \mathrm{cfu} / \mathrm{g}$. with incidence rate $6 \%, 2 \%, 2 \%$ and $2 \%$, respectively. The results of $E$. coli in Tables $(1,2)$ for Chicken luncheon, Chicken burger, Chicken sausage and Chicken shawerma were 3.4 \pm 1.8 , $3.1 \pm 1.3,3.7 \pm 2.1$ and $3.8 \pm 1.5 \log _{10} \mathrm{cfu} / \mathrm{g}$. with incidence rate $2 \%, 4 \%, 0 \%$ and $2 \%$, respectively, serologically the isolated $E$. coli indicates presence of the enterotoxigenic strains E. coli O127:H6 in chicken luncheon and E. coli $\mathrm{O} 125: \mathrm{H} 21$ and E. coli O127:H6 in chicken burger. Salmonella were not detected in Chicken luncheon, Chicken burger and Chicken sausage and detected in $2 \%$ of the examined chicken shawerma was S. typhimurium.

By PCR the results showed the presence of enterotoxin producing genes (A, C, D and E) in Staph. Aureus the three isolates of Staph. aureus isolated from luncheon showed the presence of enterotoxin gene $1^{\text {st }}(\mathrm{A}, \mathrm{E}), 2^{\text {nd }}(\mathrm{A}, \mathrm{D})$ and $3^{\text {rd }}(\mathrm{B}$, $\mathrm{D})$. The isolate of Staph. aureus isolated from burger showed presence of enterotoxin genes (A and E), the sausage isolate showed the presence of enterotoxin gene (A) while shawerma isolate showed presence of enterotoxin genes (A) .The virulence genes of shiga toxin (st $x 1$ and st $x$ ) were examined using PCR in the four $E$. coli isolates the results were postive for these genes. 
Table1: Statistical analytical results of Staph. Aureus and E. coli in the examined samples expressed as $\log _{10} \mathrm{cfu} / \mathrm{g} .(\mathrm{n}=50)$.

\begin{tabular}{ccccc}
\hline $\begin{array}{c}\text { Microbial count } \\
\log _{10} \text { cfu/gm } \pm \text { S.E. }\end{array}$ & $\begin{array}{c}\text { Chicken } \\
\text { luncheon }\end{array}$ & $\begin{array}{c}\text { Chicken } \\
\text { burger }\end{array}$ & $\begin{array}{l}\text { Chicken } \\
\text { sausage }\end{array}$ & Chicken shawerma \\
\hline STAPH.aureus & $3.2 \pm 1.6$ & $3.5 \pm 1.5$ & $3.6 \pm 1.4$ & $3.7 \pm 1.3$ \\
\hline E. coli & $3.4 \pm 1.8$ & $3.1 \pm 1.3$ & $3.7 \pm 2.1$ & $3.8 \pm 1.5$ \\
\hline
\end{tabular}

Table 2: The incidence, Serotyping and virulence gene of isolated, Staph. Aureus, E. coli and S. spp. from the examined samples ( $\mathrm{N}=50$ of each).

\begin{tabular}{|c|c|c|c|c|c|c|c|c|}
\hline samples & \multicolumn{2}{|c|}{ Chicken luncheon } & \multicolumn{2}{|c|}{ Chicken burger } & \multicolumn{2}{|c|}{ Chicken sausage } & \multicolumn{2}{|c|}{ Chicken shawerma } \\
\hline Strains & $\begin{array}{c}\mathrm{NO} \\
\%\end{array}$ & $\begin{array}{c}\text { Strains \& } \\
\text { virulence gene }\end{array}$ & $\begin{array}{c}\mathrm{NO} \\
\%\end{array}$ & $\begin{array}{c}\text { Strains \& } \\
\text { virulence gene }\end{array}$ & $\begin{array}{c}\mathrm{NO} \\
\%\end{array}$ & $\begin{array}{l}\text { Strains \& } \\
\text { virulence } \\
\text { gene }\end{array}$ & $\begin{array}{c}\mathrm{NO} \\
\%\end{array}$ & $\begin{array}{c}\text { Strains \& } \\
\text { virulence gene }\end{array}$ \\
\hline Staph. aureus & $\begin{array}{c}\mathrm{Cp} \\
3(6 \%)\end{array}$ & $\begin{array}{l}1^{\text {st }} s e a, \text { see } \\
2^{\text {nd }} s e a, \text { sed } \\
3^{\text {rd }} s e b, \text { sed }\end{array}$ & $\begin{array}{c}\mathrm{Cp} \\
1(2 \%)\end{array}$ & sea, sed & $\begin{array}{c}\mathrm{Cp} \\
1(2 \%)\end{array}$ & sea & $\begin{array}{c}\mathrm{Cp} \\
1(2 \%)\end{array}$ & sea \\
\hline E. coli & $\begin{array}{c}1 \\
(2 \%)\end{array}$ & $\begin{array}{c}\text { ETEC 0127:H6 } \\
\text { Stx } 2\end{array}$ & $\begin{array}{c}2 \\
(4 \%)\end{array}$ & $\begin{array}{c}1^{\text {st }} \\
\text { ETEC } \\
\text { O125:H21 } \\
\text { Stx } 1 \text { and stx } 2\end{array}$ & $\begin{array}{c}\text { ND } \\
-\end{array}$ & - & $\begin{array}{c}1 \\
(2 \%)\end{array}$ & $\begin{array}{c}\text { ETEC } \\
\text { O125:H21 } \\
\text { Stx1 and stx2 }\end{array}$ \\
\hline S. SPP. & ND & - & ND & - & ND & - & $\begin{array}{c}1 \\
(2 \%)\end{array}$ & $\begin{array}{l}\text { S. typhimurium } \\
\text { inv A, and stn, }\end{array}$ \\
\hline
\end{tabular}

ND. = not determined

No. $=$ number of positive samples, $\mathrm{C} \mathrm{p}=$ coagulase positive

\section{DISCUSSION}

Staph. aureus, E. coli and Salmonella are the major causes of food borne infection and intoxication and their presence in food conistitute an important hygienic problem for food processors, food handlers and consumers Bergadol (1989). The enterotoxication generally is not lethal and the elderly are more susceptible than the younger individuals, where the amount of STAPH. aureus enterotoxins required for intoxication about 94-184 ug Erol and Iseri, (2004).

The achieved results of Staph. aureus in Tables $(1 \&$ 2) for Chicken luncheon, Chicken burger, Chicken sausage and Chicken shawerma were 3.2 \pm 1.6 , $3.5 \pm 1.5, \quad 3.6 \pm 1.4$ and $3.7 \pm 1.3 \quad \log _{10} \mathrm{cfu} / \mathrm{g}$. with incidence rate $6 \%, 2 \%, 2 \%$ and $2 \%$ respectively. The results nearly similar Saleh et al. (2010) who mentioned that Staph. Aureus count were $1.14 \times 10^{3} \pm 3.32 \times 10^{2}, 2.17 \times 10^{3} \pm 4.31 \times 10^{2}$ and $2.2 \times 10^{3} \pm$ $4.45 \times 10^{2} / \mathrm{g}$. with different incidence of $4 \%, 12 \%$ and $16 \%$ for luncheon, beef-burger and sausage respectively higher percentage were reported by Amal, (2004) $15 \%$ and $25 \%$ in Staph. aureus for luncheon and fresh sausage; Fatin, (2004) could isolate Staph. Aureus from luncheon in percentage of 16\%; and Soultos et al. (2003) in percentage of $19.4 \%$ in luncheon; Mousa, (1993) reported that $S$. aureus count was $2.3 \times 10^{4} \mathrm{cfu} / \mathrm{g}$. for luncheon.;
Ahmed, (1992) 6.6\% in sausage. EL-Mossalami et al. (2009) detected Staph. aureus in 92\%, 80\% and $88 \%$ with mean values of $3.25 \pm 6 \times 10^{3}, 2.8 \pm 1.4 \times 10^{2}$ and $4.1 \pm 2 \times 10^{3} \mathrm{cfu} / \mathrm{g}$. in sausage, beef burger and shawerma respectively; Armany et al. (2016) could isolate S. aureus in percentage of $24 \%$ and $20 \%$ in raw sausage and luncheon; Shawish and AL-Humam (2016) were $12 \%, 22 \%$ and $30 \%$ in beef luncheon, beef burger and beef sausage; AL-Ghamdi, (2012) $S$. aureus count in chicken luncheon and chicken burger were $1.47 \times 10^{6}$ and $1.2 \times 10^{7} \mathrm{cfu} / \mathrm{g}$ respectively. Ibrahim, (2009) detected Staph. aureus in $22.85 \%$ and $31.85 \%$ in luncheon, and sausage and EL-Khatieb (1997) (29\%) in sausage. the percentage of coagulase positive Staph. aureus strains isolated from Chicken luncheon, Chicken burger, Chicken sausage and Chicken shawerma were $6 \%, 2 \%, 2 \%$ and $2 \%$ respectively as in Table (2). Chomvarin et al. (2006); Oh, et al. (2007) and Chiang et al. (2008) concluded that the occurrence of enterotoxigenic Staph. Raureus in ready to eat food products has been reported in various parts all over the world; Shalaby and Zaki, (2008) could isolate 4, 5 and 3enterotoxigenic strains of Staph. aureus from beef burger, sausage and shawerma respectively and Motten et al. (2011) found Coagulase positive Staph. aureus in luncheon by $7 \%, 7 \%$ and $5 \%$ from the collected samples from three supermarkets. Eldaly et al. (2014) showed that the isolation percentages of Staph. aureus in the 
examined samples of luncheon, burger, and sausage were $15 \%, 10 \%$, and $20 \%$ respectively.

The results of $E$. coli in Tables $(1,2)$ for Chicken luncheon, Chicken burger, Chicken sausage and Chicken shawerma were $3.4 \pm 1.8,3.1 \pm 1.3,3.7 \pm 2.1$ and $3.8 \pm 1.5 \quad \log _{10} \mathrm{cfu} / \mathrm{g}$. with incidence rate $2 \%, 4 \%, 0 \%$ and $2 \%$ respectively, serologically the isolated $E$. coli indicates presence of the enterotoxigenic strains E. coli O127:H6 in chicken luncheon and E. coli $\mathrm{O} 125: \mathrm{H} 21$ and E. coli $\mathrm{O} 127: \mathrm{H} 6$ in chicken burger. These results nearly similar to Samaha et al. (2012) were $8 \%$ in chicken luncheon; Ibrahim (2009) were $5.71 \%$ in luncheon; Fawzy (2004) were $8 \%$ in luncheon and Amal (2004) were 5 and $25 \%$ in luncheon and fresh sausage. Meanwhile, higher results were recorded by Armany et al. (2016) $20 \%$ and $24 \%$ in raw sausage and luncheon respectively and Mousa (1993) were $14 \%$ in luncheon; Ibrahim, (2009) were $42.85 \%$ in sausage and Fathi et al. (1992) in luncheon and sausage which were $41.67 \%$ and $20 \%$ which may be due to post processing contamination or unefficient cooking and improper handling.

Salmonella were not detected in Chicken luncheon, Chicken burger and Chicken sausage and detected in $2 \%$ of the examined chicken shawerma was $S$. typhimurium. EL Jakee et al. (2014) detect Salmonella in burger, sausage and poultry products by 10,35 and $25 \%$ respectively, the isolated Salmonella were S. enteritidis and S. typhimurium and Samaha et al. (2012) could isolate $8 \%$ Salmonella in chicken luncheon, Amal (2004); Ibrahim (2009) and Saleh et al. (2010) can not find Salmonella in luncheon while in sausage Mousa (1993); Saleh et al. (2010); Kozacinski et al. (2008); Ibrahim (2009); and Tudor et al. (2010) can't found $S$. spp. in fermented sausage. Amal (2004) found salmonella by $5 \%$ in sausage. The health hazard from Salmonella must not be underestimated. The fact that Salmonella was detected in samples from supermarkets, where chicken are displayed under refrigeration, shows that the spread of infection was not only confined to seemingly unhygienic environments FAO, (2013). It was suggested that to prevent contamination by Salmonella control measures must be taken at all stages of the food chain, from agricultural production, to processing, manufacturing and preparation of foods in both commercial establishments and at home WHO (2013).

PCR was applied to evaluate the presence of virulence genes in the isolated Staph. aureus, E. coli and Salmonella. Staph. aureus is one causes of food poisoning, its pathogenicity result from possession of virulence genes that produce different toxins which result in self-limiting sever illness. For this reason the virulence genes of 6 isolated coagulase positive Staph. aureus were examined by PCR and the results showed the presence of enterotoxin producing genes (A, C, D and E) in Staph. aureus the three isolates of Staph. aureus isolated from luncheon showed the presence of enterotoxin gene $1^{\text {st }}(A, E), 2^{\text {nd }}(A, D)$ and $3^{\text {rd }}(\mathrm{B}, \mathrm{D})$. The isolate of Staph. aureus isolated from burger showed presence of enterotoxin genes (A and E), the sausage isolate showed the presence of enterotoxin gene (A) while shawerma isolate showed presence of enterotoxin genes(A) as shown in Table (I) (Photo No. 1). The result agree with Eldaly et al. (2014) who found that luncheon samples harbored $s e b$ gene $\mathrm{s}$ while burger samples harbored sed gene also Tharwat and Elabbasy (2014) reported that SEA enterotoxin gene was the predominant enterotoxin genes which were detected in examined chicken burger and chicken luncheon.

Staph. aureus enterotoxin were analyzed from ready to eat products including pork ham, chicken cold cuts, pork sausage, salami and pork luncheon meat in a study conducted by Fijalkowski et al. (2016), this study reported that the most prevalent enterotoxin genes were sei $(36 \%)$, seln (32\%) and encoding exfoliative toxin A (37\%). Another study conducted by Puah et al. (2016) revealed an incidence of $(96.2 \%)$ virulence genes from Staph. aureus isolated from 200 food samples. A total of $30.8 \%$ of the isolates carried $S E$ gene which cause food poisoning meanwhile the most common enterotoxin genes found were $\operatorname{seg}(11.5 \%)$ and $e g c(5.8 \%)$. On the other hands Inv A and stn virulence genes in the isolated $S$. Typhimurium were positive. InvA gene was amplified and detected at $284 \mathrm{bp}$ while stn gene detected and amplified at 617 bp. In Korea, Li et al. (2006) could detect 17 virulence genes from isolated Salmonella using PCR assays, 14 genes assayed (82.4\%) out of these 17 genes included invA gene.

The virulence genes of shiga toxin (st $x 1$ and st 2 ) were examined using PCR in the four E. coli isolates the results were positive for these genes Table (2) (Photo No. 2), these results were nearly similar to Balague et al. (2006) who collected 500 food samples from shops selling ready to eat foods in Argentina and E. coli virulence gens were examined by multiplex PCR (stx1, st 2 , eae A, cnf 1 , cnf 2 , ein $\mathrm{v}$, Lt1, ST1 and ST11), ten E. coli isolates showed the presence of st 1 , stx 2 genes while other genes were negative. Another study carried by Bohaychuck et al. (2006) reported shiga toxin producing E. coli O22: $\mathrm{H} 8$ from beef samples in Alberta and Canada. 


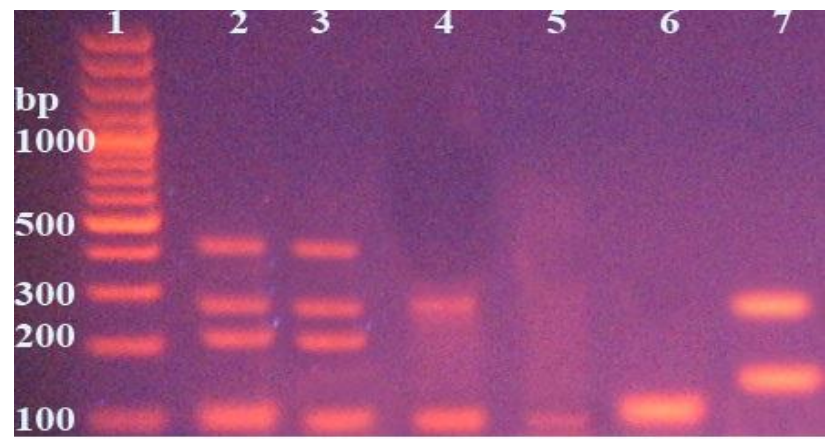

Photo No. (1): Agarose gel electrophoresis of Staph. aureus PCR products using enterotoxins Staphylococcus primer.

Lane "1": 100 bp DNA ladder

Lane "2 ": positive amplification of 102 bp for enterotoxin A, 209 bp for enterotoxin E, 278 bp for enterotoxin $\mathrm{D}$ and 451 bp for enterotoxin C

Lane "3": positive amplification of 102 bp for enterotoxin A, 209 bp for enterotoxin E, 278 bp for enterotoxin $\mathrm{D}$ and $451 \mathrm{bp}$ for enterotoxin C

Lane "4": positive amplification of 102 bp for enterotoxin A and 278 bp for enterotoxin D

Lane "5": positive amplification of $102 \mathrm{bp}$ for enterotoxin A

Lane "6": positive amplification of 102 bp for enterotoxin A

Lane "7": posistive amplification of $164 \mathrm{bp}$ for enterotoxin B and $278 \mathrm{bp}$ for enterotoxin D

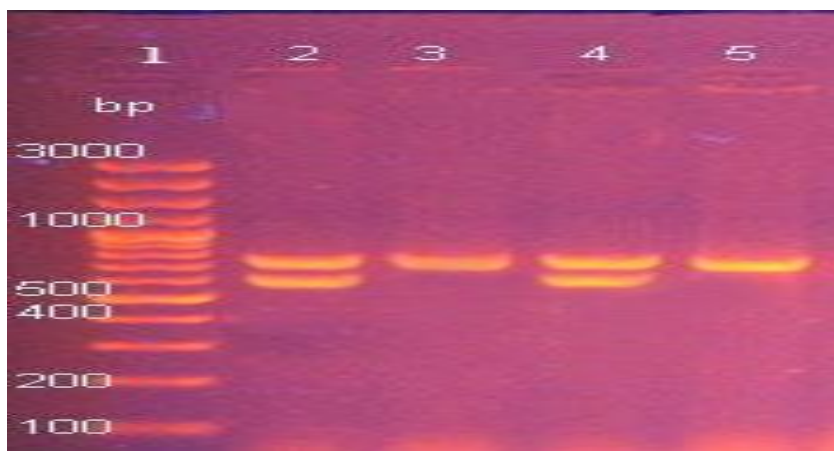

Photo No. (2): Agarose gel electrophoresis of and E. coli PCR products using stxl and stx2 primers.

Lane "1": 100 bp DNA ladder

Lane "2 ": positive amplification of 1614 bp for stx 1 gene and 779 bp for stx 2 .

Lane "3": positive amplification of $779 \mathrm{bp}$ for stx2.

Lane "4": positive amplification of $\backslash 614 \mathrm{bp}$ for stx1 gene and $779 \mathrm{bp}$ for stx2.

Lane "5": positive amplification of 779 bp for stx2.

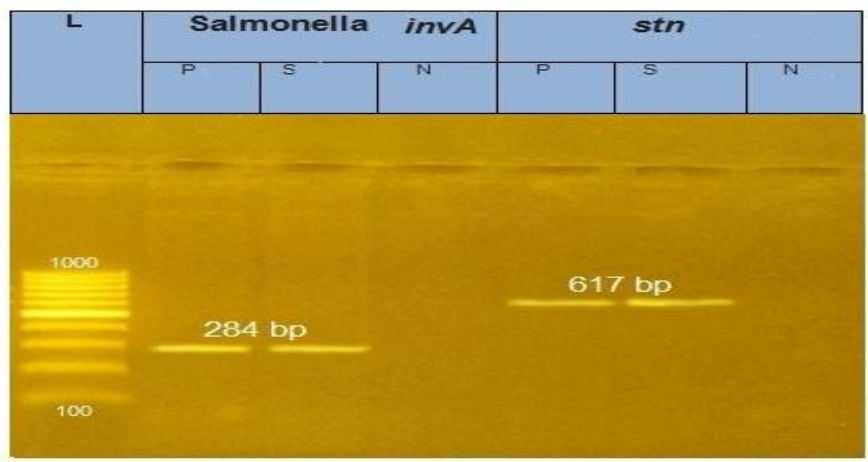

Photo No. (3): Agarose gel electrophoresis of Salmonella and PCR products using invA, and stn, primers $\mathbf{L}=100$ bp DNA ladder.

$\mathbf{N}=$ negative control.

$\mathbf{P}=$ positive control (give amplificationat $617 \mathrm{pb}$ for stn gene, $284 \mathrm{bp}$ for $i n v \mathrm{~A}, 614 \mathrm{bp}$

Sample of S.Typhimurium showed $284 \mathrm{bp}$ amplification for invA gene and $617 \mathrm{pb}$ for stn gene. 


\section{CONCLUSION}

This study confirms that chicken meat products may serve as a source of foodborne pathogens and accordingly a potential public health hazard. Corrective action needs to be employed to minimize the risk of consuming this type of fast food, such action must aim to minimizing the bacterial contamination during the production of chicken meat products (cleaning, cutting, seasoning and stacking), its cooking and serving. Regular surveillance by the public health regulatory bodies will ensure compliance with WHO and ISO standards for food safety.

Also, handling, storage and processing steps are major avenue for the cross contamination of the major materials used for the preparation of such product. Personal hygiene and processing practice of the food vendors are major factors.

\section{REFERENCES}

Ahmed, M. (1992): Incidence and Occurrence of Salmonella and E.coli in packed meat products in Assiut. M.V.Sc. thesis, Fac. of Vet. Med. Assiut University.

AL-Ghamdi, A.Y. (2012): Incidence of Staphylococcus aureus contamination of marketed processed chicken products with special refercence to its antibiotic sensitivity collected from Al Baha city markets, Saudi Arabia. Pak. J. Food Sci. 22;3: 167-169.

Amal, A.S.A.T. (2004): Trials for inhibition of some food poisoning microorganisms in meat products. Ph. D.V. Sci. Fac. Vet. Med. Cairo Univ.

Armany, G.A.; Ibrahim, M. Hemmat; Amin, R.A. and Ahmed, A. Hanaa (2016): Detection of some foodborne pathogens in meat products by Polymerase Chain Reaction. Benha Vet. Med. J. 30, 1; 323-330.

Balague, C.; Khan, A.A.; Fernandez, L.; Redolfi, A.L.; Aquili, V.; Voltattorni, P.; Hofer, C.; Ebner, G.; Duenas, S. and Cerniglia, C.E. (2006): Occurrence of non 0157 shiga toxin producing E.coli in ready to eat food from supermarkets in Argentina. Food Microbiol; 23(3): 307-313.

Bergadol, M.S. (1989): S. aureus in bacterial food borne pathogens, Editor Doyle M.P. Marcel Dekker press New York Occurrence of food borne pathogenic bacteria in refrigerated chicken meat. Hygiene Alimenter, 16, 100; 97 101.

Bohaychuck, V.M.; Gensler, G.E.; King, R.K.; Manninen, K.I.; Sorensen, O.; Wu, J.; Stiles, M.E. and McMullen, L.M. (2006): occurrence of pathogens in raw and ready to eat meat and poultry products collected from the retail market place in Edmonton, Alberta, Canada. J food Prot; 69(9): 2176-2182.

Cebedo, O.L.; Picart-i-Barrot, L. and TeixdoiCanelles, A. (2008): Prevalence of Listeria monocytogenes and Salmonella in ready - to eat food in Catalonia. Spain. J. Food Prot., 71; 4: 855-859.

Chiang, Y.C.; Liao, W.W.; Fan, C.M.; Pai, W.Y.; Chiou, C.S. and Tsen, H.Y. (2008): PCR detection of Staphylococcal enterotoxins (SEs) $\mathrm{N}, \mathrm{O}, \mathrm{P}, \mathrm{Q}, \mathrm{R}, \mathrm{U}$ and survey of SE types in $\mathrm{S}$. aureus isolates from food poisoning cases in Taiwan. Int. J. Food.

Chomavarin, C.; Chantarasuk, Y.; Srigulbur, S.; Chareonsudjai, S. and Chaicumper, K. (2006): Enteropathogenic bacteria and enterotoxinproducing Staph. aureus isolated from ready to eat food in Khon Kaen, Thailand. Southeast Asian J. Trop. Med. Public Health, 37; 983990.

Dipineto, L.; Santaniello, A.; Fontanella, M.; Lagos, K.; Fioretti, A. and Menna, L.F. (2006): Presence of Shiga toxin-producing Escherichia coli $\mathrm{O} 157: \mathrm{H} 7$ in living layer hens. Letters in Applied Microbiology 43 (2006) 293-295.

Donelly, C.B.; Leslie, J.E.; Black, L.A. and Lewis, K.H. (1967): Serological identification of enterotoxigenic Staphylococci in cheese. Appl. Microbiol.15; 1382-1389.

EL Jakee, J.; Nagwa, S. Ata; Sherein I. Abd ELMoez; Mai, M. Kandiel and Nermin, M. Radwan (2014): Assessment of the Prevalence of Salmonella in food. Int. J. of Current Microbiology Applied Sciences 3; 3: 30-42.

Eldaly, A. Elsaid.; El Shopary, F. Nermeen and El Bayomi, Rasha (2014): Detection of enterotoxigenic $S$. aureus prevalent genes in some meat products using Multiplex PCR. The 1st International Conference on Impact of Environmental Hazards on Food Safety Faculty of Veterinary Medicine- Zagazig University, 20th August, 2014.

EL-Khatieb, T. (1997): Microbiological status of Egyptian salted meat and fresh sausage. J. of Food Safety, 17 (3); 141-150.

El-Mossalami, H.H.A.; Abd-EL-Rahman, A.A. and Magdy, E.M. (2009): A study on the effect of Garlic and Nigella sativa on some food poisoning bacteria isolated from ready to- eat meat sandwiches in Alexandria City. Assiut Veterinary Medical Journal. 54; 119, 140-158.

Erol, I. and Iseri, O. (2004): Staphylococcal enterotoxins, Ankara Univeritesi Veteriner Fakultesi Dergisi, 51, 3; 239-245.

Fathi, S.M.; Rashwan, M.R. and EL-Said, S.I. (1992): Determination of coliforms and E.coli in some meat products using most probable number technique. Assiut Vet. Med. J. 24 (55): 180185. 
Fatin, S.H. (2004): Bacterial hazards associated with consumption of some meat products. Benha Vet. Med. J. 15 (2); 41-54.

Fawzy, A.A. (2004): Sudies on cooked meat and chicken products. Ph.D. Fac. of Vet. Med. Zagazig Univ. Benha branch.

FDA (2002a): Food and Drug Administration. Bacteriological Analytical Manual. $9^{\text {th }}$ Ed., AOAC International, Arlington, VA, USA.

FDA (2002b): Food and Drug Administration: Enumeration of coliform bacteria and E.coli. Bacteriological Analytical Manual. Chapter4.

Fijalkowski, K.; Peitler, D. and Karakulsuka, J. (2016): Staphylococci isolated from ready to eat meat identification, antibiotic resistance and toxin gene profile. Int J. food Microbiol.; 238:113-120.

Food and Agriculture Organization (FAO) (2013): Poultry Development Review: Poultry and poultry products: Risks for human health by $\mathrm{M}$ Ventura da Silva, FAO Document Repository. Available at: http://www.fao.org/docrep/019/ i3531e/i3531e.pd

Griffin, PM. and Tauxe, RV. (1991): The epidemiology of infections caused by Escherichia coli O157:H7, other enterohemorrhagic E. coli, and the associated hemolytic uremic syndrome. Epidemiol Rev; 13: 60-98.

Hamilton, Holds, G.; Hols, G.; Lorimer, M.; Pointon, A. and Sumner, J. (2009):Micrbiology of beef sausages at retail in Australia. Food Australia.61; 12, 532-533.

Harakeh, S.; Yassinea, H.; Ghariosb, M.; Barbourc, E.; Hajjara, S.; El-Fadeld, M.; Toufeilib, I. and Tannous, R. (2005): Isolation, molecular characterization and antimicrobial resistance patterns of Salmonella and Escherichia coli isolated from meat-based fast food in Lebanon. Sci Total Environ 341: 33 - 44.

Ibrahim, M.I.A. (2009): Bacteriological quality and shelflife of some products. M.V. Sc. Thesis. Meat Hygiene, Fac. Vet. Med. Alex. Univ. in fast food with special reference to its enterotoxigenicity. Assiut Vet. Med. J. 54,112; $37-50$

ISO, 16649/2 (2001): Microbiology of Food and Animal Feeding Stuffs-Horizontal Method for the enumeration of beta - glucuronidase positive E. coli: part 2: colony-count technique at $44^{\circ} \mathrm{C}$ using 5-bromo -4-chloro-3-indoly beta-glucuronide

ISO, 6579, (2002): Microbiology of Food and Animal Feeding Stuffs-Horizontal Method for the Detection of S. spp.

ISO, 6887/2 (2003): Microbiology of Food and Animal Feeding Stuffs-Preparation of Test Samples, Initial Suspension and Decimal Dilutions for Microb. Exam Egypt. J. Chem. Environ. Health, 1 (1):686-69
Kaneko, K.; Hayashidani, H.; Ohtomo, Y.; Kosuge, J.; Kato, M.; Takahashi, K.; Shiraki, Y. and Ogauwa, M. (1999): Bacterialcontamination of ready to eat foods and fresh products in retail shops and food factories. J Food and Drug Analysis 1: 105-115.

Kozacinski, L.; Drosinos, E.; Caklovica, F.; Cocolin, L.; Gasparik-Reichandt, J. and Eskovic, S. (2008): Investigation of microbial association of traditionally fermented sausages. Food Technology and Biotechnology.46; 1,93-106.

Lee, A.; Smith, S.C. and Coloe, P.J. (1998): Survival and growth of Campylobacter jejuni after artificial inoculation onto chicken skin as a function of temperature and packaging conditions, J. Food Protection, 61: 1609-1614.

Li, Q.; Skyberg, J.A.; Fakhr, M.K.; Sherwood, J.S.; Molan, L.K. and logue, C.M. (2006): Antimicrobial susceptibility and characterization of Salmonella isolates from processed Bison carcass. APL Microbiol 72: 3046-3049.

Matossian, R. and Kingcott, E.W. (1979): The dona kebab a possible food poisoning hazard. Environm. Health. 86; 67-68.

Mehrotra, M.; Wang, G. and Johnson, M.W. (2000): Multiplex PCR for detection of genes for Staphylococcus aureus enterotoxin, exfoliative toxins, toxic shock syndrome toxin 1 , and Methicillin resistance. Journal of Clinical Microbiology, Vol. 38: 1032-1035.

Motten, Vanessa; Fisch Elisa and Cardoso Marisa (2011): Microbial contamination of luncheon meat sliced and packaged in supermarkets in Porto Alegre, Brazil. Acta Scientiae Veterinariae, 39; 1: 940-945.

Mousa, M.M.; Awad, H.A.; Yassien, M.M. and Gouda, H.I. (1993): Microbial quality of some meat products.Vet. Med. J. Giza. 41; 3,59-62.

Murugkar, H.V.; Rahman, H. and Dutta, P.K. (2003): Distribution of virulence genes in Salmonella serovars isolated from man and animals. Indian J. Med. Res., 117:66-70.

Oh, S.K.; Lee, N.; Cho, Y.S.; Shin, D.B.; Choi, S.Y. and Koo, M. (2007): Occurrence of toxigenic Staph. Aureus in ready to eat food in Korea. J. Food Protection, 70; 1153-1158.

Oliveira, S.D.; Rodenbusch, C.R.; Ce, M.C.; Rocha, S.L.S. and Canal, C.W. (2003): Evaluation of selective and non-selective en-richment PCR procedures for Salmonella de-tection. Lett. Appl. Microbiol., 36: 217-221.

Osek, J. and Wieczorek, K. (2010): Zoonosis and their etiological agents in the EFSA report for 2008. ZycieWeterynaryjne. 2010. 85: 4, 315324.

Pelczar, MJ.; Chane, CS. and Kreig, NR. (2006): Microbiology 5th edition. Tata McGraw-Hill Publishing Company Limited, New Delhi.

Puah, S.M.; Chua, K.H. and tan, J.A. (2016): virulence factor and antibiotic susceptibility of 
Staph. Aureus isolates in ready to eat foods: detection of Staph. aureus contamination and a high prevalence of virulence genes. Int. J. Environ Res public health 5; 13(2)199.

Saleh, E.A.; Ali, H.A. and Abu-Khadra, A.M. (2010): Detection of some food poisoning microorganisms in some meat products. Alex. J. Vet. Sc. 31; 1, 27-33.

Samaha, I.A.; Ibrahim, H.A.A. and Hamada, M.O. (2012): Isolation of some enteropathogens from retailed poultry meat in Alexandria Province. Alex. J. Vet. Science 37; 1: 17-22.

SAS Institute (2003): SAS Proprietary Software. Re. 9.1. SAS Instit. Inc. Cary, NC.

Shalaby, M. Amany and Zaki, M.S. Eman (2008): Occurrence of Staphylococcus aureus in fast food with special reference to its enterotoxigenicity. Assiut Vet. Med. J. 54,112: 37-50.

Shawish, R.R. and AL-Humam, N.A. (2016): Contamination of beef products with Staphylococcal classical enterotoxin in Egypt and Saudi Arabia. Hygiene and Infection Control, 11; ISSN 2196-5226.
Soultos, N.; Abrahim, A. and Abrosiadis, I. (2003): Incidence of some food borne bacterial pathogens in northern Greece. Archiv Staph. Furer Lebensmittel. Hygiene 54,(3);55-57.

Tharwat, A. Elsayed and Elabbasy, M. Tharwat (2014): Classical Staphylococcus aureus Enterotoxins genes in some chicken meat products marketed in Zagazig city, Egypt. The 1 st International Conference on Impact of Environmental Hazards on Food Safety Faculty of Veterinary Medicine- Zagazig University, 20th August, 2014.

Tsang, O. (2002): Guidelines for Ready-To-Eat Food. Road and Environmental Hygiene Department, Hong Kong.pp. 15 - 16

Tudor, L.; Togoe, I. and Mitranescu, E. (2010): The microbiological quality analysis of some meat products traded on Bucharest markets. Lucrari Stiintifice-Universitatea de Stiinte Agricole a Banatului Timisoara, Medicina Veterinara. 40; 688-693.

World Health Organization (WHO) (2013): MEDIA Centre, Fact sheet $\mathrm{N}^{\circ} 139$ : Salmonella (nontyphoidal), Available at: http://www.who. nt/ media centre/ factsheets/fs139/en.

\section{مدى تواجد جينات الضر اوة ببعض البكتيريا المنقولة بالغذاء في بعض منتجات لحوم الدواجن

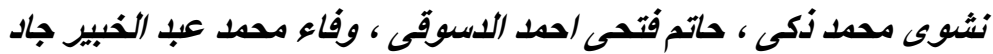

Email: nashwazaki80@gmail.com

Assiut University web-site: www.aun.edu.eg

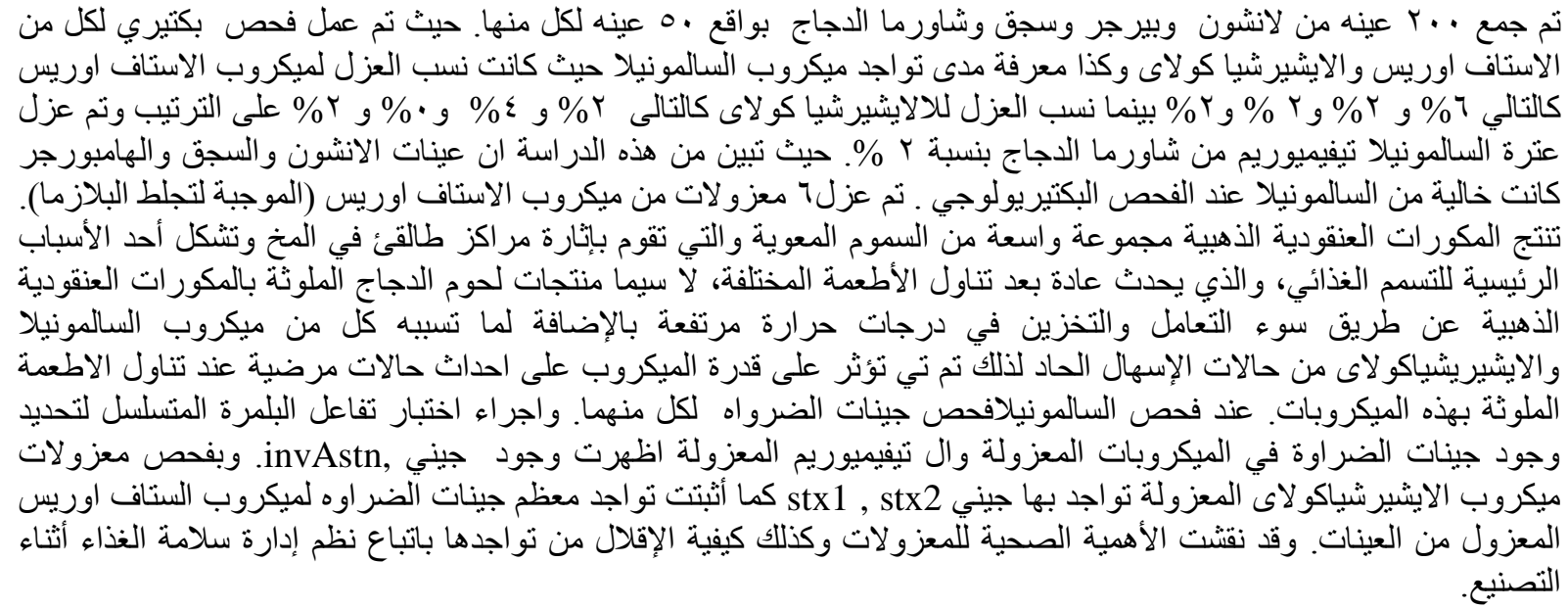

